\title{
Performance of Islamic Boarding Schools in developing the beef cattle agribusiness partnership network as a community empowerment institution in Central Java
}

\author{
J. T. Harjanto, E. Prasetyo, S. I. Santoso and E. Rianto* \\ Faculty of Animal and Agricultural Sciences, Diponegoro University, \\ Tembalang Campus, Semarang, 50275 - Indonesia \\ *Corresponding E-mail: erianto_05@yahoo.com
}

Received September 12, 2018; Accepted November 25, 2018

\begin{abstract}
ABSTRAK
Suatu penelitian telah dilakukan untuk mengevaluasi kinerja Pondok Pesantren Agribisnis (PPA) dalam mengembangkan jejaring kemitraan agribisnis sapi potong di Jawa Tengah. Penelitian ini melibatkan 24 PPA dengan setiap PPA dipilih dua orang responden, yaitu seorang berasal dari internal (santri) dan seorang berasal dari eksternal (masyarakat peternak). Penentuan sampel menggunakan metode purposive sampling. Penelitian ini menggunakan Analisis Kesenjangan dengan menentukan nilai Indeks Kepuasan Pengguna (IKP). Data primer dikumpulkan melalui pengamatan langsung dan wawancara dengan responden. Data sekunder diperoleh dari institusi pemerintah terkait. Hasil penelitian menunjukkan bahwa jejaring kemitraan agribisnis sapi potong yang dibangun oleh PPA masih belum memuaskan para santri dan masyarakat peternak di sekitarnya (IKP.s. total : 30,73\% dan IKP.f.total: 47,05\%). Disimpulkan bahwa masyarakat peternak sangat antusias menjalin kemitraan agribisnis sapi potong dengan PPA; para santri memerlukan penambahan kurikulum peternakan; PPA memerlukan pelatihan dan pendampingan dari pihak lain (pemerintah, pihak swasta, dll.) agar dapat meningkatkan kemampuan beternak sapi potong dan kemampuan dalam melatih, menyuluh dan merencanakan pengembangan peternakan sapi potong di wilayah sekitarnya. Peningkatan kemampuan PPA otomatis dapat meningkatkan efektivitas peranan PPA sebagai lembaga pemberdayaan masyarakat di sekitarnya

Kata kunci: Pondok Pesantren, sapi potong, kemitraan, pemberdayaan masyarakat
\end{abstract}

\begin{abstract}
A study had been conducted to evaluate the performance of Islamic Boarding Schools (IBS) in developing the beef cattle agribusiness partnerships network in Central Java. This study involved 24 IBS with each IBS selected two respondents, namely one from internal (santri) and one from external (farmer community). Sample determination uses purposive sampling method. This study uses Gap Analysis by determining the Customer Satisfaction Index (CSI) value. Primary data were collected through direct observation and interviews with respondents. Secondary data was obtained from relevant government institutions. The results showed that the beef cattle agribusiness partnership network that was developed by IBS still did not satisfy for santries and farmer communities $\left(\mathrm{CSI}_{\text {s.total }}: 30.73 \%\right.$ and $\mathrm{CSI}_{\text {.f.total }}:$ 47.05\%). It was concluded that farmer communities were very enthusiastic about establishing the beef cattle agribusiness partnerships with IBS; the santries needed additional livestock curriculums; IBS needed training and assistance from the other parties (government, private sector, etc.) in order to improve the ability to raise beef cattle and the ability to train, instruct and plan the beef cattle farming development in surrounding area. Increasing the ability of IBS automatically can increase the
\end{abstract}


effectiveness of IBS role as an empowerment institution for surrounding community

Keywords: Islamic Boarding School (IBS), beef cattle, partnership, community empowerment

\section{INTRODUCTION}

The partnership is an important thing to empower the livestock community, in making cooperation with agribusiness agents from production to marketing stages, based on the principle of equality, mutual need, and benefit, as well as sharing costs, risks, and benefits (Saptana and Ashari, 2007; Suryana, 2009). Quer et al. (2010) stated that maximizing partnership performance is the nature of the organization, which motivates collaboration between various parties and also acts as the principle of stabilization and governance of the organization's network. Several studies have shown that commitment to stable cooperative relations affects the performance of partnerships (Fynes et al., 2005; Krause et al., 2007), and produces competitive advantages (Fu et al., 2013).

Utilization of social capital is important in accelerating agricultural development, namely efforts to empower social elements consisting of social institutions, norms, ethics, and regulations related to productive activities of the local sector (Suradisastra and Lubis, 2000). One of the social institutions that exist in the society and participate in the agribusiness development in Central Java is Pondok Pesantren (Islamic Boarding School; IBS). IBS as a religious institution generally had natural resources in the form of land to agribusiness development, human resources (santries: student who studying in IBS, farmer communities around IBS, and role models that greatly influenced the local community), wellestablished institutions and has many members and spread everywhere, and has well social relations with local community, so it becomes potential as an extension and training of animal farming, and has a strategic institution for developing rural animal farming (Hanani, 2005; Direktorat Jenderal Peternakan, 2009).

The beef self-sufficiency program is the main target for livestock development, as stated in the Ministry of Agriculture's Strategic Plan for the period 2015 - 2019. The achievement of beef selfsufficiency requires the utilization of the roles and functions of institutional and human resources of animal husbandry (Biro Perencanaan Kementerian Pertanian, 2015). Development of beef cattle through partnership patterns can be well received by farmers, the government, and the private sector, and they active as development actors (Sumanto, 2013). The need for human resources and institutions agribusiness, as well as an agribusiness through partnership patterns in order to succeed beef self-sufficiency is a momentum for various stakeholders, including IBS with insight into beef cattle farming to further develop livestock agribusiness (Direktorat Jenderal Peternakan, 2009). IBS is expected to grow and develop as a centre for training, extension and education (BPPSDMP Kementerian Pertanian, 2007).

IBS is a religious institution that is deeply rooted in society and has become a socio-cultural part of society, especially in rural areas, so that it has the opportunity to become one of the drivers of the agricultural economy in the countryside (Widodo, 2010). The IBS specified on beef cattle agribusiness is expected by the government to be an institution that could empower farmers around IBS. However, there is no evaluation yet about the effectiveness of IBS partnership that needed for developing a model for further implementations, so this study was conducted to evaluate the IBS partnership.

\section{MATERIALS AND METHODS}

\section{Location and Characteristics of Samples}

This study was conducted at 24 IBS in Central Java that were active in the empowerment of the beef cattle farmers and had agribusiness unit that an organizational structure separate from the parent IBS unit. Determination of samples in each IBS was done by purposive sampling method. Every IBS consisted of two respondents who were active in beef cattle farming, namely one person from internal IBS (the santri who studying in IBS) and one person from IBS external (the farmer community around IBS).

\section{Data Collection}

The data collected included primary and secondary data. The primary data were collected by direct observation and interviews based on the questionnaire with the santries who studying in IBS and the farmer communities around IBS. The questionnaire contained the identity of respondents, and six variables such as the ability 
to cooperate with the farmer partners, the ability to cooperate with the other parties/ private sector, the ability to cooperate with the training/ internship partners, the ability to deliver the livestock extension, the ability to organize the regular meetings, and the ability to plan the livestock development.

\section{Methods of Analysis}

The collected data were used for the CSI (Customer Satisfaction Index) calculation, then analyzed by Gap Analysis. The CSI calculation was done following Aritonang (2005).

Firstly, the Mean Importance Score (MIS) was calculated by the following formula. This value was derived from the average of the variable on each respondent (the santri who studying in IBS and the farmer community around IBS) as a representative IBS. MIS is calculated to determine the importance level of each variable based on the average of importance partnership network variables at each respondent as a representative of IBS customer or user.

$$
\text { MIS }_{i}=\frac{\sum_{i=1}^{n} Y_{i}}{n}
$$

$\mathrm{n}$ : number of respondents (person)

$\mathrm{Yi}$ : value of variable $\mathrm{Y}$ to - $\mathrm{i}$ (score)

Secondly, the calculation of the Weight Factors (WF). This WF was calculated by dividing the MIS of each variable to MIS of total variables. WF is calculated to determine the weighting of variable factor based on the percentage of importance level on each partnership network variable in the IBS.

$$
\mathrm{WF}_{\mathrm{i}}=\frac{\mathrm{MIS}_{\mathrm{i}}}{\sum_{\mathrm{i}}^{\mathrm{p}} \mathrm{MIS}_{\mathrm{i}}} \times 100(\%)
$$

$\mathrm{i}-\mathrm{p}$ : variavles of $\mathrm{i}$ to $\mathrm{p}$

Thirdly, calculation of MSS (Mean Satisfaction Score) was done by dividing total MIS to the number of variables. MSS is calculated to determine the average of level satisfaction in all variables based on the score of importance in each partnership network variable in the IBS.

$$
\operatorname{MSS}=\frac{\left[\sum_{i}^{p} M_{i S}\right]}{p}
$$

Fourthly, calculation of Weight Score (WS) was done by multiplying the WF with MSS. WS is calculated to determine the weighting of the score based on the factor weight of each variable with the average of level satisfaction in all partnership network variables in the IBS.

$$
\mathrm{WS}_{\mathrm{i}}=\mathrm{WF}_{\mathrm{i}} \mathrm{x} \text { MSS (in \%) }
$$

Fifthly, determine The Customer Satisfaction Index (CSI). CSI is calculated to determine the level of overall IBS customer or user satisfaction by the level of importance of all partnership network variables in the IBS.

$$
\mathrm{CSI}=\frac{\left[\sum_{\mathrm{i}}^{\mathrm{p}} \mathrm{WS}_{\mathrm{i}}\right]}{\mathrm{HS}} \times 100(\%)
$$

HS : Highest scale (maximum scale $=4$ )

The value of CSI in this study was classified into 5 (five) scales of stakeholders satisfaction (Table 1) according to Oktaviani and Suryana (2006).

\section{RESULTS AND DISCUSSION}

\section{The Ability to Cooperate with the Farmer Partners}

The beef cattle agribusiness cooperation developed by IBS with the farmer partners (the santries and the farmer communities) was presented in Table 2 and Table 3. The cooperation was classified as less effective for the santries in IBS (39.58\%) but was quite effective for the farmer communities around IBS (64.58\%).

The santries involvement by IBS were classified as less effective. This situation was caused by two factors, namely the limited time and experience of santri. The time spent by santri in raising cattle was limited, which was only about $13 \%$ (2 hours) of the total hours of santri activity every day (15 hours) in IBS. Beyond this time, santri must conduct their obligations for formal school, religious activities, and other extracurricular activities. The experience of santri in raising livestock was also a cause of low effectiveness because santries were still in the learning stage. This is consistent with the statement of Mardyanto (2016), that santri involvement in the entrepreneurial process is limited by the need to study religion and study in formal schools. According to Kadir (2015), santri must be involved in managing agribusiness activities in order to get benefits in the form of livestock skills for their future, exemption from 
Table 1. The Value of Stakeholder Satisfaction

\begin{tabular}{lccccc}
\hline \multirow{2}{*}{ Value } & \multicolumn{5}{c}{ Scale of Satisfaction } \\
\cline { 2 - 6 } & Not Satisfied & Less Satisfied & Quite Satisfied & Satisfied & Very Satisfied \\
\hline Unit of Scale & 0 & 1 & 2 & 3 & 4 \\
CSI (\%)* & $0-34$ & $35-50$ & $51-65$ & $66-80$ & $81-100$ \\
Effectiveness & Not & Less & Quite & Effective & Very \\
\hline
\end{tabular}

* The five criteria of Customer Satisfaction Index (CSI) value based on Oktaviani and Suryana (2006)

Table 2. The Effectiveness of Beef Cattle Agribusiness Partnership Network Performance Developed by IBS for The Santri who Studying in IBS

\begin{tabular}{lrrrrrrr}
\hline \multicolumn{1}{c}{ Value } & \multicolumn{1}{c}{ Y.s $_{1}$} & \multicolumn{1}{c}{ Y.s $_{2}$} & \multicolumn{1}{c}{ Y.s $_{3}$} & \multicolumn{1}{c}{ Y.s $_{4}$} & \multicolumn{1}{c}{ Y.s $_{5}$} & Y.s $_{6}$ & Y.s \\
\hline Variable Y.s \\
MIS
\end{tabular}

Y.s $\mathrm{s}_{1}=$ the ability to cooperate with the santri; Y.s. $\mathrm{s}_{2}=$ the ability to cooperate with other parties for the santri; $\mathrm{Y} . \mathrm{s}_{3}=$ the ability to cooperate with training/internship partners for the santri; Y. $\mathrm{s}_{4}=$ the ability to deliver the livestock extension for the santri; Y.s. $\mathrm{s}_{5}=$ the ability to organize the regular meetings for the santri; Y. $\mathrm{s}_{6}=$ the ability to plan the livestock development for the santri; Y.s $\mathrm{s}_{\text {total }}=$ the partnership network of beef cattle agribusiness for the santri; MIS $_{\mathrm{i}}=$ Mean Importance Score from the average of variable $\mathrm{Y}_{\mathrm{i}}$; MSS = Mean Satisfaction Score; $\mathrm{WF}_{\mathrm{i}}=$ Weight Factors of variable $\mathrm{Y}_{\mathrm{i}} ; \mathrm{WSi}=$ Weight Score of variable Yi; CSI.s $=$ Customer Satisfaction Index for the santri

education fees, even receiving pocket money, and this can provide education fees waivers for poor students. According to Salloum and Kabbani (2011), educational institutions need to create jobs for students who have graduated so that they are not unemployed.

The IBS that cooperation with farmer communities were quite effective because IBS enforces the livestock raising system that is entrusted (penggaduhan). This system has a positive impact on the communities around the IBS through a system of business profit sharing and utilization of livestock business workers. Agribusiness cooperation networks would automatically be formed. The value of $64.58 \%$ (Table 3) was only $1.42 \%$ to be classified as effective (Table 1). This condition is because there were still obstacles faced by farmers in developing their livestock agribusiness, namely limited feed. This limitation was due to the lack of knowledge about IBS in calculating the count of livestock with the potential for an available feed so that the resulting product was less optimal. According to Sobron et al. (2015), The IBS need to involve the surrounding community as work partners. Livestock raising that is entrusted conduct by surrounding community groups and organized by religious institutions has been running but has not achieved the expected results (Sonbait et al., 2011).

Based on the discussion above, there are efforts to achieve the effectiveness of IBS 
Table 3. The Effectiveness of The Beef Cattle Agribusiness Partnership Network Performance Developed by IBS for The Farmer Community Around IBS

\begin{tabular}{|c|c|c|c|c|c|c|c|}
\hline Value & Y.f & Y.f $f_{2}$ & $\mathrm{Y.f}_{3}$ & Y.f $_{4}$ & Y.f $_{5}$ & Y.f $_{6}$ & Y.f total \\
\hline Variable Y.. $f_{\mathrm{i}}$ & 62.00 & 28.00 & 26.00 & 34.00 & 83.00 & 38.00 & 271.00 \\
\hline $\mathrm{MIS}_{\mathrm{i}}$ (score) & 2.58 & 1.17 & 1.08 & 1.42 & 3.46 & 1.58 & 11.29 \\
\hline MSS (score) & & & & & & & 1.88 \\
\hline $\mathrm{WF}_{\mathrm{i}}(\%)$ & 22.88 & 10.33 & 9.59 & 12.55 & 30.63 & 14.02 & 100.00 \\
\hline $\mathrm{WS}_{\mathrm{i}}(\%)$ & 43.06 & 19.44 & 18.06 & 23.61 & 57.64 & 26.39 & 188.19 \\
\hline CSI.f (\%) & 64.58 & 29.17 & 27.08 & 35.42 & 86.46 & 39.58 & 47.05 \\
\hline Effectiveness & Quite & Not & Not & Less & Very & Less & Less \\
\hline
\end{tabular}

Y. $f_{1}=$ the ability to cooperate with the farmer community; Y. $f_{2}=$ the ability to cooperate with other parties for the farmer community; Y. $f_{3}=$ the ability to cooperate with training/internship partners for the farmer community; Y. $f_{4}=$ the ability to deliver the livestock extension for the farmer community; $Y . f_{5}=$ the ability to organize the regular meetings for the farmer community; Y. $\mathrm{f}_{6}=$ the ability to plan the livestock development for the farmer community; Y. $\mathrm{f}_{\text {total }}=$ the partnership network of beef cattle agribusiness for the farmer community; MIS $_{\mathrm{i}}=$ Mean Importance Score from the average of variable $\mathrm{Y}_{\mathrm{i}}$; MSS = Mean Satisfaction Score; $\mathrm{WF}_{\mathrm{i}}=$ Weight Factors of variable $\mathrm{Y}_{\mathrm{i}} ; \mathrm{WS}_{\mathrm{i}}=$ Weight Score of variable $\mathrm{Y}_{\mathrm{i}}$; CSI.f $=$ Customer Satisfaction Index for the farmer community

cooperation with farmer partners (the santries and the farmer communities). Increasing the effectiveness of cooperation with the santri can be done through the addition of an agricultural curriculum. The addition of curriculum can automatically increase the time and experience of the santri as new entrepreneurs. This is consistent with the opinion of Edelman et al. (2008), that IBS must bridge the differences between entrepreneurial education material and the actual conditions needed by new entrepreneurs.

Development of cooperation with the farmer community can be done through the addition of administrators in the IBS who have skills of livestock technical and management, including recruitment of administrators from the farmer community. The farming ability can be obtained through training and assistance from related government agency/other parties. Dzanja et al. (2013), stated that farmer with low managerial ability cannot utilize technology in livestock farming. Training is needed by farmer to improve managerial skills so that they can increase their business scale (Khusna et al., 2016).

\section{The Ability to Cooperate with the Other Parties/Private Sector}

The agribusiness cooperation developed by
IBS with the other parties was presented in Table 2 and Table 3. The agribusiness cooperation was classified as not effective for the santries in IBS $(22.92 \%)$ and the community farmers around IBS (29.17\%).

IBS was not effective in establishing agribusiness cooperation with the other parties/ private sector, due to of inequality in establishing cooperation. IBS has established agribusiness cooperation with the other parties/private sector, but it has not been done again. Based on Table 2 and Table 3, the ability to develop the internal collaboration of IBS with the beef cattle farmers have not reached an effective level. This indicator was the reason for IBS collaboration with the other parties/private sector was not continuing.

Based on the discussion above, the efforts made to achieve the effective value of IBS cooperation with other parties/private sector were through increasing insight into cooperation with other parties/private sector that support the beef cattle agribusiness in IBS. According to Abidin et al. (2015), the development of beef cattle agribusiness conduct together with other parties can provide optimal results. Optimal business results can be input for increasing education funding in IBS as an educational institution. Low funding levels will result in poor facilities and 
cause the curriculum to become less innovative (Hall, 2006). Some ways to find sources of funds from other parties for educational institutions are; creating relationships with individuals, alumni, government, companies, and foundations $(\mathrm{Li}$, 2014), involving partnerships between elements of society with a cost-sharing system from the government and private parties (Kanaan, 2011), non-funding sources more innovative and realistic governments such as waqf, fees, international assistance (foreign grants), investment and other internal income generated (Robert-Okah, 2011), funding sources in the form of school fees, government funds, private sector contributions, alumni, sales of agricultural and handicraft products, teacher associations and parents (Nwafor et al., 2015).

\section{The Ability to Cooperate with the Training/Internship Partners}

The cooperation of livestock training/internship developed by IBS with training partners was presented in Table 2 and Table 3. The collaboration was classified as not effective for the santries $(22.92 \%)$ and the farmer communities around IBS (27.08\%).

The IBS were not effective in developing cooperation of farm training/internship with related training partners because the IBS did not understand the training material needed by the surrounding farmers. Lack of IBS knowledge in technical and managerial of beef cattle farming causes the selection of trainers to be inappropriate so that the material presented was not suitable for the needs of farmers or santri. This reason was supported by a discussion about IBS cooperation with farmer partners which obtained results that IBS was still weak in technical and management of beef cattle farming. Based on the above discussion, the effort to improve the effectiveness of training/ internship cooperation was through understanding the training/internship materials needed by IBS administrators and their farmer partners (santries, communities) and conducted intensively. Intensive training was conduct to improve the ability of farmers in managerial and utilization of appropriate livestock technology (Isbandi, 2004).

\section{The Ability to Deliver the Livestock Extension}

The livestock extension delivered by IBS was presented in Table 2 and Table 3. The livestock extension was classified as not effective for the santries in IBS (15.63\%) and less effective for the farmer communities around IBS (35.42\%).

The IBS had not been effective in delivering livestock extension to the farmer partners because there were problems in the selection of extension methods used. The ability of IBS to deliver livestock extension for the farmer communities were higher than the effectiveness for santri. IBS that communicate more often with santri actually had a lower effectiveness value than the farmer community around IBS. It is strongly suspected that there were supporting aspects from the farmer communities that were more able to receive the livestock extension because they were accustomed to receiving the extension material, while extension material for santri was still something new.

The ability of IBS in delivering extension material to the farmer partners had not yet reached the effective level. The values of $15.63 \%$ (Table 2) and $35.42 \%$ (Table 3) have distance $40.37 \%$ and $30.58 \%$ to achieve effective value $(66 \%)$. This very large difference was not only due to the lack of accuracy of IBS in the selection of extension methods but also due to the lack of accuracy of IBS in the selection of materials needed for the farmer partners (the santries and the farmer communities).

Based on the above discussion, the effort to improve the effectiveness of livestock extension was through increasing the ability of IBS in the selection of delivery methods and extension material to be delivered. The method of extension for the farmer community must be distinguished if the treatment is given to the santri. The extension material for the farmer community was conveyed through the andragogy method (adult education). The extension material for the santri can be delivered on the sidelines of formal education routines (school, reciting Al-Qur'an: pengajian, extracurricular activities, etc.). According to Santa et al. (2016), the extension philosophy is based on the needs of farmers and the process of nonformal education for adults. The extension activities need to be conducted repeatedly (continuously without stopping) until the farmers are able to apply the knowledge and technology of livestock delivered.

\section{The Ability to Organize the Regular Meetings}

The regular meetings in the IBS with the farmer partners (the students and the farmer communities) were presented in Table 2 and Table 3 . The regular meetings of agribusiness activities were classified as less effective for the santries in 
IBS $(50.00 \%)$ but very effective for the farmer communities around IBS (86.46\%).

The IBS were less effective in conducting regular agribusiness meetings with the santries. The Value of $50.00 \%$ (Table 2) was only $0.1 \%$ to be classified as quite effective (Table 1). Almost approaching is quite effective because the santries actually had the regular meetings, only the habit was done by direct/spontaneous consultation to organizer or the elder santri. Whereas according to Handriyanta et al. (2012), the beef cattle agribusiness in religious institutions still requires regular meetings in the framework of monitoring, mentoring, and sustainable guidance for farmers as congregation or santri at the institution.

IBS was very effective in conduct regular agribusiness meetings at least once a month with farmer communities around IBS. There was community enthusiasm to hold regular meetings by IBS which is an entrepreneurial institution, because this activity was used as a means to socialize and share livestock problems. The regular meeting was held by IBS in the form of discussion forums, coordination, coaching, and mentoring, as a manifestation of social responsibility for the community. According to Graafland et al. (2006), muslim entrepreneurs have a positive view and the intensity of their religious activities have a significant relationship to socially responsible business behavior.

\section{The Ability to Plan the Livestock Development}

Planning for livestock development in the surrounding area designed by IBS is presented in Table 2 and Table 3. The planning was classified as not effective for the santries (33.33\%), and less effective for the farmer communities around IBS (39.58\%).

IBS had not been effective in planning for the development of livestock in the surrounding area. This condition was because the planning conduct by IBS was not accordance with the needs of the farmer partners (santri, farmer community) due to the inability of IBS in seeing the potential of human resources and natural resources to develop beef cattle farming. The inability was linear with the previous discussion, that IBS still had weaknesses in mastery in the beef cattle agribusiness, especially the need for renewal. In fact, according to Hamruni (2016), the IBS were expected to be able to unravel intelligently the present problems with contemporary approaches.
Based on the discussion, the effort to improve the effectiveness of livestock development planning was through the improvement of IBS capabilities in planning that are tailored to the needs of the farmer partners in surrounding area. The farmer partners as beneficiaries of livestock activities in IBS must be involved in livestock development planning. This was in line with the opinion of Sumanto (2013), that the development of beef cattle must involve the role of farmers since the beginning of planning. According to Mardyanto (2016), agribusiness management begins with planning decisions in order to support the agribusiness production process. Planning is needed to build a positive synergy between expenditure and efficient cost creation (Effendi, 2015).

\section{CONCLUSION}

The farmer communities around IBS were very enthusiastic in conduct livestock activities, including holding regular meetings, and this had become a big asset for IBS to develop the beef cattle agribusiness partnerships. The santri in IBS need to be given additional curriculum for livestock. The IBS need to be given training and assistance from other parties (government, private sector, etc.), in order to improve ability to raise beef cattle and ability to train, extend and plan the beef cattle farming development. Inproving the IBS ability can increase the effectiveness of IBS performance as an empowerment institution for the surrounding community.

\section{REFERENCES}

Abidin, Z., A.R. Siregar, H. Khurniyah and A. Yahya. 2015. The analysis of seasonal crops integration of income-beef cattle live stock in Bone Country Bolango Gorontalo Province Indonesia. Int. J. Curr. Res. Acad. Rev. 3(6): 148-159.

Aritonang, R.L. 2005. Kepuasan Pelanggan. PT. Gramedia Pustaka Utama. Jakarta.

Biro Perencanaan Kementerian Pertanian. 2015. Rencana Strategis Kementerian Pertanian Tahun 2015-2019. Kementerian Pertanian. Jakarta.

BPPSDMP Kementerian Pertanian. 2007. Pedoman Penumbuhan dan Pengembangan P4S. BPPSDMP Kementerian Pertanian. Jakarta.

Canaan, T.H. 2011. Political economy of cost 
sharing in higher education: the case of Jordan. Prospect. 41(1): 23-45.

Direktorat Jenderal Peternakan. 2009. Petunjuk Pelaksanaan Pemberdayaan dan Pengembangan Usaha Agribisnis Peternakan LM3. Kementerian Pertanian. Jakarta.

Dzanja, J., P. Kapondamgaga and H. Tchale. 2013. Value chain analysis of beef in Central and Southern Malawi (case studies of Lilongwe and Chikhwawa Districts). Int. J. Bus. Soc. 4(6): 92-102.

Edelman, L.F., T.S. Manolova and C.G. Brush. 2008. Entrepreneurship education: correspondence between practices of nascent entrepreneurs and textbook prescriptions for success. Acad. Manage. Learning Edu. 7(1): 56-70.

Effendi, M.S. 2015. A management model of financing and the use of research products in public service agencies. Eur. J. Economics, Finance and Administrative Sciences. 81(2015):104-116.

Fu, S., J. Lin and L. Sun. 2013. An empirical examination of the stability of the alliance of "a company + farmers". Chin. Manage. Studies. 7(3): 382-402.

Fynes, B., C. Voss and S.D. Burca. 2005. The impact of supply chain relationship quality on quality performance. Int. J. Prod. Economics. 96(3): 339-354

Graafland, J., C. Mazereeuw and A. Yahia. 2006. Islam and socially responsible business conduct: an empirical study of Dutch entrepreneurs. Bus. Ethics: A Eur. Rev. 15(4): 390-406.

Hall, J. 2006. The dilemma of school finance reform. J. Social, Political, and Economic Studies. 31(3):175-190.

Hamruni. 2016. The challenge and the prospect of pesantren in historical review. J. Islamic Edu. 5(2): 413-429.

Hanani, N. 2005. Peranan Kelembagaan dalam Pengembangan Agribisnis. Pamator. 2(1). LPPM. Universitas Trunojoyo. Bangkalan.

Handriyanta, G.A.N., I.W. Sudarta and I.D.P.O. Suardi. 2012. Perilaku petani terhadap program pemberdayaan dan pengembangan usaha agribisnis peternakan. E-J. Agribisnis dan Agrowisata. 1(1):11-15.

Isbandi. 2004. Pembinaan kelompok petani-ternak dalam usaha ternak sapi potong. J. Indon. Trop. Anim. Agric. 29(2):106-114.

Kadir, A.M. 2015. Pemberdayaan santri di
Pondok Pesantren Attarbiyaussakilah Kota Kendari. J. Al Qalam. 21(2):221-234.

Kanaan, T.H. 2011. Political economy of cost sharing in higher education: the case of Jordan. Prospect. 41(1): 23-45.

Khusna, A., H.K. Daryanto and M.M.D. Utami. 2016. Pengembangan strategi agribisnis sapi potong di Kabupaten Bondowoso. J. Ilmu Pertanian Indonesia. 21(2):69-75.

Krause, D.R., R. Handfield and B. Tyler. 2007. The relationships between supplier development, commitment, social capital accumulation and performance improvement. J. Operations Manag. 25: 528-545.

Li, Y.Y. 2014. Financing, management, and public relation at The University of Houston and its implication for China. Chin. Edu. Soc. 47(2):56-70.

Mardyanto, E. 2016. Manajemen kewirausahaan pondok pesantren berbasis agrobisnis. J. Fikroh. 9(2):199-219.

Nwafor, N.E., E.E. Uchendu and C.O. Akani. 2015. Need for adequate funding in the administration of secondary education in Nigeria. Global J. Edu. Res. 14(1):119-124.

Oktaviani, R.W. and R.N. Suryana. 2006. Analisis kepuasan pengunjung dan pengembangan fasilitas wisata agro (studi kasus di Kebun Wisata Pasirmukti, Bogor). J. Agro Ekonomi. 24(1):41-58.

Quer, D., E. Claver and L. Rienda. 2010. Doing business in China and performance: a review of evidence. Chin. Manage. Studies. 4(1):37-56.

Robert-Okah, I. 2011. Financing higher education in Nigeria: implications for University Governance. J. Edu. Rev. 4(3):395-402.

Salloum, S. and N. Kabbani. 2011. Implication of financing higher education for access and equity: The case of Syria. Prospect. 41(1):97-113.

Santa, N.M., Z. Tamod and J. Pandey. 2016. Pemberdayaan kelompok peternak sapi sebagai sumberdaya pendukung Badan Usaha Milik Rakyat di Kelurahan Malalayang I Timur. Proceedings, Seminar Nasional Peternakan 2, Fakultas Peternakan, Universitas Hasanuddin, Makasar, August 25, 2016. P. 110-116.

Saptana and Ashari. 2007. Pembangunan pertanian berkelanjutan melalui kemitraan usaha. J. Litbang Pertanian. 26(4):126-130.

Shobron, S., I. Rosyadi, Z. Suaidy and 
Mohammad. 2015. Dakwah Bil-hal Pesantren Walisongo Ngabar Ponorogo Jawa Timur dalam pemberdayaan ekonomi masyarakat tahun 2013 - 2014. Profetika. J. Studi Islam. 16(1):26-49.

Sonbait, L.Y., K.A. Santoso and Panjono. 2011. Evaluasi program pengembangan sapi potong gaduhan melalui kelompok lembaga mandiri yang mengakar di masyarakat di Kabupaten Manokwari Papua Barat. Buletin Peternakan. 35(3): 208-217.

Sumanto. 2013. Pemberdayaan peternak sapi potong melalui kemitraan bagi hasil di Kalimantan. Balai Penelitian Ternak Bogor.
Seminar Nasional Teknologi Peternakan dan Veteriner. Medan, September 3 - 4, 2013. P. 50-258.

Suradisastra, K. and A.M. Lubis. 2000. Aspek gender dalam penelitian peternakan. Wartazoa. 10(1):13-19.

Suryana. 2009. Pengembangan usaha ternak sapi potong berorientasi agribisnis dengan pola kemitraan. J. Litbang Pertanian. 28(1):2937.

Widodo, S. 2010. Pengembangan potensi agribisnis dalam upaya pemberdayaan ekonomi pondok pesantren (kajian ekonomi - sosiokultural). Embryo. 7(2): 111-116. 